\title{
Indigenous Knowledge about Consumption of Edible Insects in South Africa
}

\author{
Zabentungwa T. Hlongwane*(D), Rob Slotow and Thinandavha C. Munyai (D) \\ School of Life Sciences, University of KwaZulu-Natal, Private Bag x 01, Scottsville 3209, South Africa; \\ Slotow@ukzn.ac.za (R.S.); munyaic2@ukzn.ac.za (T.C.M.) \\ * Correspondence: nolwazihlongwane20@gmail.com
}

check for updates

Citation: Hlongwane, Z.T.; Slotow, R.; Munyai, T.C. Indigenous Knowledge about Consumption of Edible Insects in South Africa. Insects 2021, 12, 22. https://doi.org/10.3390/ insects 12010022

Received: 30 November 2020 Accepted: 28 December 2020 Published: 31 December 2020

Publisher's Note: MDPI stays neutral with regard to jurisdictional clai$\mathrm{ms}$ in published maps and institutional affiliations.

Copyright: (C) 2020 by the authors. Licensee MDPI, Basel, Switzerland. This article is an open access article distributed under the terms and conditions of the Creative Commons Attribution (CC BY) license (https:// creativecommons.org/licenses/by/ $4.0 /)$.
Simple Summary: Edible insects are a natural resource rich in protein, fats, vitamins, amino acids, and minerals such as zinc and iron. Consumption of insects is a traditional practice in many African countries. Edible insects are consumed for their nutritional value and play an essential role in human nutrition across Africa. We conducted questionnaires intending to document indigenous knowledge regarding the consumption of insects, and collection and preparation methods used by rural people in Limpopo and KwaZulu-Natal (KZN), provinces of South Africa. We found that most people still consume insects in Limpopo while fewer people do so in KZN. In KZN, respondents cited that the decline in entomophagy might be caused by the adoption of western diets, discomfort associated with eating insects, and the decline in the availability of insects from the wild. Mopane worms and termites were the most preferred insects in Limpopo and KwaZulu-Natal, respectively. Edible insects contribute to human nutrition and play an important role in improving the livelihoods of people in rural areas of South Africa. As a result, people should be encouraged to include edible insects in their daily diets.

Abstract: Consumption of edible insects is an indigenous practice that has played an essential role in human nutrition across Africa. The traditional use of insects forms an important part of food culture in Africa, and insects are consumed either as a delicacy, emergency, or staple source of food. However, indigenous knowledge about insect consumption is being lost because recent generations have adopted western methods and paid less attention to traditional practices. We conducted 500 questionnaires in five local municipalities in Kwazulu-Natal (KZN), and 122 questionnaires in four local municipalities in Vhembe district in Limpopo, South Africa, to document indigenous knowledge about edible insects' consumption, collection, and preparation methods used in Limpopo and KZN. Eight insect species belonging to five insect orders were used as food in Limpopo and KZN, with mopane worms (94\%) and termites (70\%) being the most preferred species by respondents in Limpopo and KZN, respectively. Ninety-five percent of the respondents occasionally consumed insects in Limpopo, while only $28 \%$ did so in KZN. Nutritional benefits and tradition were the main reasons for consuming insects. Edible insects are a nutritious diet and play an important role in people's livelihoods in rural areas. However, there was a notable decline in entomophagy, particularly in KZN. The decline may be related to occidental acculturation, discomfort associated with eating insects, and declining insect availability. To promote entomophagy, the authorities should encourage people to include edible insects in their diets because of their nutritional value. In addition, edible insect flour should be incorporated in food products such as biscuits, bread, energy bars, cereal, and cookies to promote acceptability.

Keywords: edible insects; entomophagy; nutritional benefits; mopane worm; termites

\section{Introduction}

Entomophagy is an ancient indigenous practice that has played a significant role in human nutrition around the world [1,2]. Edible insects are an important protein source, 
and their consumption plays an important role in food security and improving rural livelihoods [2-5]. They are consumed as a traditional food in different regions, including Latin America [6], China [7,8], Thailand [1,9], Mexico [10,11], Japan [12,13], and Africa [14-22]. The traditional use of insects as food in these countries is not a new practice, as it dates back as far as the history of mankind [10-12]. However, consumption of insects is not well accepted in western countries and still remains unexplored, because of barriers such as fear and disgust associated with eating insects [23-26]. In addition, in developed countries, eating insects is considered primitive, unclean, or food of the poor [24]. In Africa, approximately 500 species of insects are used as food in different countries [5,27]. On this continent, edible insects are consumed either as a staple, an emergency food source during times of food shortage, or an important delicacy $[22,28]$. Consumption and preference of edible insects differ geographically [22]. For example, some people prefer consuming insects, either fried, roasted, or raw, and others may find eating insects disgusting [5,14]. In some African countries, certain species are only consumed in one region and are of traditional importance; for example, stink bugs (Hemiptera: Tessaratomidae) are only consumed and are a delicacy for the vhaVenda people in the Limpopo province of South Africa [15].

In South Africa, edible insects have formed part of the human diet since prehistoric times; for example, Ledger [29] reported that South Africans consumed Trinervitermes trinervoides (a termite) and Apis mellifera unicolor (a honeybee) in early 100,000 BCE. In addition, Quin [20] and Bodenheimer [30] reported an ongoing consumption of edible insects for nutritional benefits by the baPedi people in South Africa in the early 1950s. Nowadays, in South Africa, edible insects are mostly consumed in Limpopo province by vhaVenda, baPedi, and Vatsonga people [13,15,31]. In addition, they are also consumed in Mpumalanga, KwaZulu-Natal [32], North West, and Gauteng [15]. The groups of edible insects consumed in South Africa are various Lepidopteran caterpillars, termites, grasshoppers, jewel beetles, ants, and stink bugs $[13,15,29,33]$. Edible insects are an important natural resource available to vulnerable people and provide earning opportunities to traders and harvesters [31,34-37]. In addition, edible insects play an important role in food security, rural livelihoods, and poverty eradication [34]. For example, Makhado et al. [33] reported that trading edible insects results in an income of approximately US $\$ 202,915$ per trader during one season. Edible insects create seasonal employment opportunities for unemployed people across southern Africa, reducing poverty and improving human wellbeing [31,34].

Malnutrition and food shortage are the major challenges experienced in developing countries [38]. According to Voster [39], most people in South Africa are food-insecure and do not have access to nutritious food to meet their daily nutrient requirements. Edible insects are consumed because they are a nutritious traditional food source that has been used to supplement diets across Africa over many years [22]. In addition, consumption of insects is good for human wellbeing, as the nutritional value of edible insects can help promote human health, and reduce the vulnerability to malnutrition of children, pregnant women, and older people [40]. Edible insects can also improve the well-being of vulnerable people living with malnutrition, child stunting, and macronutrient deficiencies [41-44].

Over the years, there has been a notable decrease in entomophagy in developing countries, particularly in urban areas $[4,21]$. The younger generation, especially in urban areas, has little or no knowledge about insects' consumption [4]. This is thought to result from people adopting western/modern food culture and, therefore, abandoning traditional practices such as entomophagy [4]. Globalization and westernization have influenced what people eat [23]. As a result, people are more reliant on western food, and they are more reluctant to try traditional food such as edible insects, as they are now perceived as dirt or a taboo $[4,23,44]$. This has led to several people being wary of accepting insects as food or even distancing themselves from consuming insects $[4,23,45]$. Yet, edible insects are rich in protein, carbohydrates, amino acids, and micronutrients, such as zinc and iron [5].

Little attention has been paid to documenting indigenous knowledge on insects' consumption as an important traditional practice in South Africa [46-48]. The traditional understanding of entomophagy among indigenous people is rich but restricted because 
it is orally passed through generations, and some has been lost in translation over the years $[1,49]$. Mostly, rural communities have no tools or resources to document their indigenous knowledge about practices that play an important role in their communities. As a result, indigenous knowledge is lost because recent generations have adopted western methods and paid less attention to traditional practices $[4,50]$. Combining indigenous knowledge about entomophagy with scientific research will further improve the understanding of the role of edible insects as a food resource for people [49]. In addition, documenting indigenous knowledge about edible insects will help promote and preserve entomophagy [4]. The current study, therefore, aims to (1) document indigenous knowledge relating to the consumption patterns, methods, or techniques used in the collection, and preparation of insects in South Africa; (2) determine the most consumed or preferred insect species; (3) access the perception of edible insects; and (3) determine the factors influencing the consumption of edible insects in South Africa.

\section{Materials and Methods}

\subsection{Study Site}

The study was conducted in villages at KwaZulu-Natal and Limpopo provinces, South Africa. In KwaZulu-Natal, sampling was conducted in five villages (Swayimane, Umbumbulu, Nhlazuka, Tugela Ferry, and Kokstad) of the uMshwathi, eThekwini, Richmond, uMsinga and Greater Kokstad local Municipalities, while in Limpopo, sampling was conducted in several villages of the Mutale, Makhado, Thulamela, and Musina local Municipalities of Vhembe District Municipality (see Table A1). In the villages surveyed, the population size ranged from 86 to 4099 in Limpopo and 2000 to 7903 in KwaZulu-Natal $(\mathrm{KZN})[51,52]$ (Table 1$)$. These villages were selected because consumption of insects mainly forms part of their tradition. However, we are not undermining the other nearby or known villages in South Africa where edible insects' consumption is also practiced.

Table 1. Population size of local municipalities surveyed in KwaZulu-Natal (KZN) and Limpopo provinces.

\begin{tabular}{cc}
\hline Municipalities & Population Size \\
\hline Limpopo & \\
Makhado & 416,728 \\
Thulamela & 497,237 \\
Mutale & 91,870 \\
Musina & 32,009 \\
KZN & \\
uMshwathi & 10,374 \\
Richmond & 65,793 \\
uMsinga & 160,000 \\
Greater Kokstad & 51,561 \\
eThekwini & $3,702,231$ \\
\hline
\end{tabular}

Adapted from [51,52].

\subsection{Questionnaires}

Questionnaires made up of closed and open-ended questions were conducted in KZN ( $n=500)$ in August 2019 and Vhembe district municipality $(n=122)$ in December 2019, by visiting local peoples' households to obtain their perspective on the subject of eating insects. The respondents were chosen randomly by approaching people door to door in their households (see Appendix B). The KZN sample was larger as there was more variability in answers, and the villages were more extensive and further apart. Questionnaires were conducted through face-to-face interviews. Questions assessed respondents' knowledge about edible insects, ways of assessing insects, processing and preparing, reasons for eating insects, how often they consumed insects, the benefits of eating insects, and their attitude towards eating insects. In addition, respondents were asked to list the names of the insects consumed or used as food in their villages. Respondents were provided with pictures of 
different edible insects taken from the guide of insects of Southern Africa [53] and from the internet, to select the species consumed, or previously consumed, in their villages. In addition, as part of a separate study, we purchased edible insects from all the traders we interviewed in markets in Vhembe district, and these were used to identify the insects consumed. Questionnaires were written and presented by a first-language-speaking author using local languages isiZulu (KZN, ZTH) and Tshivenda (TCM) in Vhembe district of Limpopo. Demographic information of the respondents who participated in the study in both provinces are presented in (Tables 2 and 3)

Table 2. Demographic information of the respondents in five local municipalities, KwaZulu-Natal ( $n=500)$, South Africa.

\begin{tabular}{|c|c|c|c|c|c|c|}
\hline Demographics & KZN Overall (\%) & Greater Kokstad & Richmond & UMshwathi & uMsinga & eThekwini \\
\hline \multicolumn{7}{|l|}{ Age category (years) } \\
\hline Under 18 & 8 & 9 & 8 & 9 & 9 & 6 \\
\hline 18-24 years & 18 & 13 & 9 & 24 & 23 & 23 \\
\hline $25-34$ & 15 & 19 & 22 & 10 & 13 & 11 \\
\hline $35-44$ & 10.6 & 14 & 9 & 7 & 11 & 12 \\
\hline $45-54$ & 11.2 & 10 & 10 & 12 & 11 & 13 \\
\hline $55-64$ & 15.8 & 15 & 23 & 15 & 15 & 11 \\
\hline $65-74$ & 11.8 & 12 & 13 & 13 & 8 & 13 \\
\hline 75 years and above & 9 & 8 & 6 & 10 & 10 & 11 \\
\hline \multicolumn{7}{|l|}{ Sex } \\
\hline Male & 40 & 41 & 40 & 42 & 40 & 37 \\
\hline Female & 60 & 59 & 60 & 58 & 60 & 63 \\
\hline \multicolumn{7}{|l|}{ Level of education } \\
\hline No formal education & 23 & 20 & 27 & 14 & 26 & 30 \\
\hline Primary education & 37 & 39 & 44 & 34 & 33 & 34 \\
\hline Secondary education & 32 & 26 & 26 & 44 & 32 & 33 \\
\hline Tertiary education & 8 & 15 & 3 & 8 & 9 & 3 \\
\hline \multicolumn{7}{|l|}{ Occupation } \\
\hline Unemployed & 32 & 30 & 35 & 22 & 28 & 46 \\
\hline Self employed & 11 & 9 & 15 & 12 & 13 & 6 \\
\hline Pensioner & 32 & 34 & 37 & 34 & 25 & 29 \\
\hline Employed & 15 & 18 & 8 & 19 & 21 & 10 \\
\hline Student & 10 & 9 & 5 & 13 & 13 & 9 \\
\hline
\end{tabular}

This study has been ethically reviewed and approved by the University of KwaZuluNatal Human and Social Sciences Research Ethics Committee (approval number HSS / 0125/ 019D). Permission to conduct research in various villages in all the local municipalities was obtained from community leaders. All participants provided informed consent to participate in the study, and data were anonymised, treated confidentially, and stored securely. 
Table 3. Demographic information of the respondents in four local municipalities in the Vhembe district, Limpopo province $(n=122)$.

\begin{tabular}{|c|c|c|c|c|c|}
\hline Demographics & $\begin{array}{c}\text { Limpopo } \\
\text { Overall (\%) }\end{array}$ & Thulamela & Makhado & Musina & Mutale \\
\hline \multicolumn{6}{|l|}{ Age category (years) } \\
\hline Under 18 & 9 & 0 & 9 & 1 & 1 \\
\hline 18-24 years & 16 & 7 & 6 & 4 & 2 \\
\hline $25-34$ & 23 & 16 & 7 & 4 & 2 \\
\hline $35-44$ & 12 & 5 & 6 & & 4 \\
\hline $45-54$ & 13 & 11 & 4 & & 1 \\
\hline $55-64$ & 13 & 8 & 4 & & 2 \\
\hline $65-74$ & 11 & 9 & 4 & & 2 \\
\hline 75 years and above & 4 & 3 & & & 2 \\
\hline \multicolumn{6}{|l|}{ Sex } \\
\hline Male & 48 & 28 & 18 & 5 & 7 \\
\hline Female & 52 & 32 & 19 & 4 & 9 \\
\hline \multicolumn{6}{|l|}{ Level of education } \\
\hline No formal education & 7 & 7 & 1 & 1 & \\
\hline Primary education & 14 & 11 & 2 & & 4 \\
\hline Secondary education & 57 & 24 & 32 & 6 & 8 \\
\hline Tertiary education & 22 & 6 & 16 & 1 & 3 \\
\hline \multicolumn{6}{|l|}{ Occupation } \\
\hline Unemployed & 60 & 30 & 25 & 8 & 10 \\
\hline Self employed & 18 & 13 & 6 & & 3 \\
\hline Pensioner & 17 & 11 & 7 & & 3 \\
\hline Employed & 5 & 3 & 2 & 1 & \\
\hline
\end{tabular}

\subsection{Data Analysis}

Data from the questionnaires were coded and entered into an excel spreadsheet. A chisquare test of independence was used to determine if there were any significant differences in consumption pattern of edible insects across local municipalities. To determine if there were significant differences in factors influencing the choice to consume insects, a Generalized Linear Model (GLM) was used. Count data of respondents are presented in percentages. The GLM and chi-square test analysis were performed using IBM SPSS Statistics version 26 (SPSS Inc., Chicago, IL, USA).

\section{Results}

\subsection{Insect Consumption Pattern}

Eight species belonging to five insect orders were consumed as food in the Vhembe district and KZN (Table 4). In KZN, termites were consumed consistently $\left(X^{2}{ }_{4}=2.243\right.$, $p=0.619)$ at about $70 \%$ of respondents across the five villages, while edible locust $(6-40 \%)$ and Cirina forda $(0-19 \%)$ were consumed less, with significant differences across the villages (locust: $X^{2}{ }_{4}=59.313, p<0.001$; Cirina forda: $X^{2}{ }_{4}=44.457, p<0.001$ ) (Table 5). 
Table 4. Traditional collection and preparation methods of the commonly consumed insects in KZN and Limpopo provinces of South Africa.

\begin{tabular}{|c|c|c|c|c|c|c|c|}
\hline Insects Group & Insect Order & $\begin{array}{c}\text { Consumption } \\
\text { Stage }\end{array}$ & Seasonality & $\begin{array}{l}\text { Method of } \\
\text { Collection }\end{array}$ & Collectors & $\begin{array}{l}\text { Processing for } \\
\text { Preservation } \\
\text { Method }\end{array}$ & $\begin{array}{l}\text { Cooking } \\
\text { Method }\end{array}$ \\
\hline $\begin{array}{l}\text { Gynanisa } \\
\text { caterpillar }\end{array}$ & Lepidoptera & Larvae & $\begin{array}{l}\text { November- } \\
\text { January }\end{array}$ & $\begin{array}{l}\text { Collected from } \\
\text { the host plant }\end{array}$ & Women & $\begin{array}{c}\text { Degutted, } \\
\text { washed, boiled } \\
\text { in salt water, } \\
\text { and sun-dried }\end{array}$ & $\begin{array}{c}\text { Fried, roasted, } \\
\text { or as a relish }\end{array}$ \\
\hline $\begin{array}{c}\text { Mopane } \\
\text { worms } \\
\text { (Imbrasia belina) }\end{array}$ & Lepidoptera & Larvae & $\begin{array}{c}\text { Nov-January; } \\
\text { April-May }\end{array}$ & $\begin{array}{l}\text { Collected from } \\
\text { Colophosper- } \\
\text { mum } \\
\text { mopane }\end{array}$ & Women & $\begin{array}{c}\text { Degutted, } \\
\text { washed, boiled } \\
\text { in salt water, } \\
\text { and sun-dried }\end{array}$ & $\begin{array}{l}\text { Fried, boiled } \\
\text { without salt, } \\
\text { boiled with } \\
\text { salt, roasted, or } \\
\text { as a relish }\end{array}$ \\
\hline $\begin{array}{c}\text { Termites } \\
\text { (Macrotermes } \\
\text { species) }\end{array}$ & Blattodea & Winged adult & $\begin{array}{l}\text { September- } \\
\text { January }\end{array}$ & $\begin{array}{l}\text { Trapped in a } \\
\text { large bowl of } \\
\text { water near the } \\
\text { light source }\end{array}$ & Women & $\begin{array}{l}\text { Killed with } \\
\text { boiling water, } \\
\text { boiled, and } \\
\text { sun-dried }\end{array}$ & $\begin{array}{l}\text { Fried and } \\
\text { roasted }\end{array}$ \\
\hline $\begin{array}{c}\text { Stinkbug } \\
\text { (Encosternum } \\
\text { delegorguei) }\end{array}$ & Hemiptera & Adult & May-August & $\begin{array}{l}\text { Picked from } \\
\text { woodlands }\end{array}$ & Women & $\begin{array}{c}\text { Killed with } \\
\text { warm water, } \\
\text { cooked, and } \\
\text { dried }\end{array}$ & Fried, roasted \\
\hline Cirina forda & Lepidoptera & Larvae & Nov-Feb & $\begin{array}{l}\text { Picked from } \\
\text { the host tree }\end{array}$ & Women & $\begin{array}{c}\text { Degutted, } \\
\text { washed, boiled } \\
\text { in salt water, } \\
\text { and sun-dried }\end{array}$ & $\begin{array}{l}\text { Fried, boiled, } \\
\text { boiled with } \\
\text { salt, roasted, or } \\
\text { as a relish }\end{array}$ \\
\hline $\begin{array}{c}\text { Edible } \\
\text { grasshop- } \\
\text { per/locust } \\
\text { (Locustana and } \\
\text { Zonocerous } \\
\text { species) }\end{array}$ & Orthoptera & Adult & & $\begin{array}{l}\text { Picked from } \\
\text { grassland }\end{array}$ & $\begin{array}{l}\text { Women and } \\
\text { children }\end{array}$ & $\begin{array}{l}\text { Dewinged, } \\
\text { degutted, } \\
\text { killed in hot } \\
\text { water and } \\
\text { roasted }\end{array}$ & Fried, roasted \\
\hline Carebara vidua & Hymenoptera & Adult & All year round & $\begin{array}{l}\text { Picked from } \\
\text { grassland }\end{array}$ & $\begin{array}{l}\text { Women and } \\
\text { children }\end{array}$ & Eaten raw & Eaten raw \\
\hline Cicadoidea spp. & Hemiptera & Adult & & $\begin{array}{l}\text { Picked from } \\
\text { grasslands }\end{array}$ & & $\begin{array}{l}\text { Killed with } \\
\text { warm water, } \\
\text { cooked, } \\
\text { and dried }\end{array}$ & Fried, roasted \\
\hline
\end{tabular}

Table 5. Percentage of respondents that consumed insects across five municipalities in KZN, South Africa.

\begin{tabular}{ccccccc}
\hline Insects & $\begin{array}{c}\text { Greater } \\
\text { Kokstad }\end{array}$ & Richmond & uMshwathi & uMsinga & eThekwini & Average \\
\hline Termites & 74 & 72 & 65 & 67 & 70 & 70 \\
Edible & 6 & 6 & 34 & 40 & 19 & 22 \\
locust & 0 & 1 & 13 & 19 & 2 & 8 \\
Cirina forda & 0 & & & & & \\
\hline
\end{tabular}

Mopane worms were consumed consistently $\left(X^{2}{ }_{3}=1.664, p>0.05\right)$ at about $94 \%$ of the respondents across villages in Limpopo, followed by termites (85\%) and edible grasshoppers $(84 \%)$ with no significant differences across villages (termites $X^{2}{ }_{3}=12.475$, $\mathrm{df}=3, p<0.05 ; 11.407, \mathrm{df}=3, p<0.05$; edible grasshopper $\left.X^{2}{ }_{3}=11.990, \mathrm{df}=3, p<0.05\right)$, while Encosternum delegorguei (stink bug) (19\%), Gynanisa caterpillar (18\%), Carebara vidua. $(15 \%)$, and Cicadoidea (1\%) were consumed less, with no significant differences across villages (stink bug: $\left.X^{2}{ }_{3}=3.398, p>0.05\right)$; lepidopteran caterpillar: $\left(X^{2}{ }_{3}=1.406,3 p>0.05\right)$, Carebara vidua $\left(X^{2}{ }_{3}=0.72, p>0.05\right)$, and Cicadoidea spp. $\left(X^{2}{ }_{3}=5.715, p>0.05\right)$ (Table 6). 
Table 6. Percentage of respondents that consumed insects across four municipalities in Vhembe district in Limpopo, South Africa.

\begin{tabular}{cccccc}
\hline Insects & Thulamela & Makhado & Musina & Mutale & Average \\
\hline Mopane worm & 100 & 97 & 90 & 97 & 96 \\
Termites & 97 & 97 & 83 & 70 & 86 \\
Gynanisa & 16 & 13 & 20 & 10 & 14 \\
caterpillar & 16.6 & 16.6 & 30 & 13 & 19 \\
Stink bug & 97 & 97 & 76 & 73 & 85 \\
Edible & 16.6 & 13.3 & 20 & 13.3 & 15 \\
grasshopper & 0 & 0 & 6.6 & 0 & 2 \\
Carebara spp. & & & & & \\
Cicadoidea spp. & & &
\end{tabular}

There were no significant differences in the number of people who have never consumed insects, the people who have consumed insects in their lifetime, and the people who still consume insects $\left(X^{2}{ }_{8}=9.041, p>0.05\right)$ in KZN. However, there were significant differences in people who have never consumed insects, the people who have consumed insects in their lifetime, and those who still consume insects $\left(X^{2}{ }_{6}=13.395, p<0.05\right)$ in Limpopo. A greater percentage of respondents reported having consumed at least one insect species in their lifetime in Limpopo (98\%) compared to KwaZulu-Natal (64\%), with $95 \%$ still practicing entomophagy in Limpopo compared to only $28 \%$ in KwaZulu-Natal. Thirty-five percent of KZN respondents reported that they used to consume insects ( $2 \%$ who cited that they used to consume insects in the past in Limpopo; the percentage is low because of the high number who currently consume). KZN had a greater number (36\%) of respondents who had never consumed insects than in Limpopo (only $3 \%$ ).

There were significant differences in factors affecting the choice to eat insects in $\mathrm{KZN}\left(X^{2}{ }_{15}=35.233, p<0.05\right)$ and in Limpopo $\left(X^{2}{ }_{19}=35.145, p<0.05\right)$. In KZN, age $\left(X^{2}{ }_{7}=23.764, p<0.05\right)$ and educational background $\left(X^{2}{ }_{4}=11.208, p<0.05\right)$ were the factors that influenced the choice to eat insects, while in Limpopo, employment status $\left(X^{2}{ }_{3}=10.913, p<0.05\right)$ and gender $\left(X^{2}{ }_{1}=3.378, p<0.05\right)$ were the factors that influenced the choice to eat insects (Tables 7 and 8 ).

Table 7. Factors affecting choice to consume insects in KZN, South Africa.

\begin{tabular}{cccc}
\hline Factors & Chi-Square & df & $p$ Value \\
\hline Gender & 1.080 & 1 & 0.299 \\
Age & 23.765 & 7 & 0.001 \\
Educational & 11.208 & 3 & 0.011 \\
background & 4.662 & 4 & 0.324 \\
Occupation & & & \\
\hline
\end{tabular}

Table 8. Factors affecting choice to consume insects in Limpopo, South Africa.

\begin{tabular}{cccc}
\hline Factors & Chi-Square & df & $p$ Value \\
\hline Gender & 3.738 & 1 & 0.053 \\
Age & 6.748 & 7 & 0.456 \\
Educationalbackground & 2.014 & 3 & 0.570 \\
Occupation & 10.913 & 4 & 0.002 \\
\hline
\end{tabular}

\subsection{Reasons for Consuming Insects, or Not}

Nutritional benefits of insects and traditional beliefs were the primary reason for practicing entomophagy in KwaZulu-Natal ( $43 \%$ and 38\%, respectively) and Limpopo (66\% and $21 \%$, respectively) (Figure 1 ). 


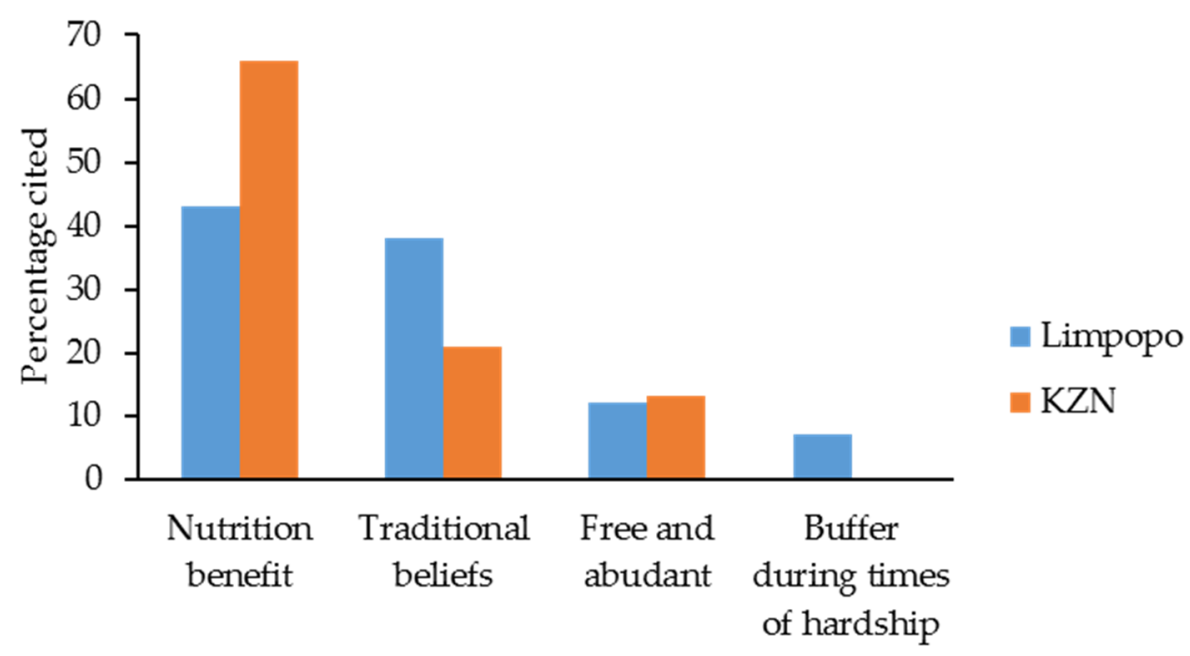

\section{Reason for consuming insects}

Figure 1. Reasons for consuming insects in Limpopo and KZN provinces of South Africa.

The most cited reasons (36\%) for not consuming insects in KZN were fear and discomfort associated with consuming insects, adoption of western food culture $(27 \%)$, followed by a lack of knowledge about entomophagy (12\%), and a decrease in the availability of edible insects in the wild (10\%) (Figure A1). In Limpopo, 3\% of the respondents cited religious beliefs as a reason for not consuming insects. In comparison, only $2 \%$ cited dislike and discomfort associated with eating insects as a reason for stopping eating insects. Respondents did not include cost as a reason for not consuming insects, because in KZN, insects were collected from the wild, and in Limpopo, insects were also collected from the wild and sold for R20-R30 a cup in town.

There were significant differences in reasons for consuming edible insects among respondents of different genders $\left(X^{2}{ }_{1}=6.361, p=0.012\right)$ and age group $\left(X^{2}{ }_{7}=78.308\right.$, $p=0.001)$; however, there were no significant differences in reasons for consuming edible insects among respondents with different educational backgrounds $\left(X^{2}{ }_{4}=2.567, p=0.633\right)$ and employment status $\left(X^{2}{ }_{4}=1.635, p=0.802\right)$ in $\mathrm{KZN}$. In Limpopo, there were significant differences in reasons for consuming insects among respondents of different genders $\left(X^{2}{ }_{1}=10.215, p=0.001\right)$, ages $\left(X^{2}{ }_{1}=44.568, p=0.001\right)$, and employment status $\left(X^{2}{ }_{3}=30.850\right.$, $p=0.001)$. However, there were no significant differences in reasons for consuming insects among respondents with different educational backgrounds $\left(X^{2}{ }_{3}=4.746, p=0.191\right)$.

There were significant differences in reasons for not consuming edible insects among different genders $\left(X^{2}{ }_{1}=5.213, p=0.019\right)$, ages $\left(X^{2}{ }_{7}=15.967, p=0.025\right)$, and educational backgrounds $\left(X^{2}{ }_{4}=13.525, p=0.009\right)$; however, there were no significant differences in reasons for not consuming insects among respondents with different employment status $\left(X^{2}{ }_{4}=1.366, p=0.850\right)$ in $\mathrm{KZN}$. On the other hand, there were no significant differences in reasons for not consuming edible insects among respondents of different genders $\left(X^{2}{ }_{1}=0.078, p=0.780\right)$, ages $\left(X^{2}{ }_{7}=4.231, p=0.753\right)$, educational backgrounds $\left(X^{2}{ }_{3}=0.559, p>0.906\right)$, and employment status $\left(X^{2}{ }_{3}=2.246, p>0.523\right)$.

\subsection{Frequency of Consumption}

There were no significant differences in insect consumption frequency across local municipalities in $\mathrm{KZN}\left(\mathrm{X}^{2}{ }_{4}=1.680, p=0.794\right)$. The majority $(59-71 \%)$ of the respondents rarely consume insects (at least once a month), while fewer respondents (1-6\%) consumed insects regularly (1-4 times a month) in KZN (Figure A2). The frequency of insect consumption did not differ significantly $\left(X^{2}{ }_{9}=15.317, p=0.083\right)$ across local municipalities in Limpopo; $33-57 \%$ of the respondents consumed insects occasionally while only $24-40 \%$ consumed insects at least once a month (Figure A2). 
There were significant differences in frequency of edible insect consumption among different genders $\left(X^{2}{ }_{1}=6.980, p=0.008\right)$ and ages $\left(X^{2}{ }_{7}=70.704, p=0.001\right)$; on the other hand, there were no significant differences in frequency of edible insect consumption among respondents with different educational backgrounds $\left(X^{2}{ }_{4}=2.970, p=0.563\right)$ and employment backgrounds $\left(\mathrm{X}^{2}{ }_{4}=0.748, p=0.945\right)$ in KZN. There were no significant differences in frequency of edible insect consumption among different genders $\left(X^{2}{ }_{1}=0.020\right.$, $p=0.928)$, ages $\left(X^{2}{ }_{7}=0.028, p>0.05\right)$, educational backgrounds $\left(X^{2}{ }_{3}=0.034, p>0.05\right)$, and employment status $\left(X^{2}{ }_{3}=0.048, p>0.05\right)$ in Limpopo.

\subsection{Preparation and Collection Methods}

Seasonal availability, collection, and preparation methods of edible insects differed from one species to another (Table 4). All respondents collected insects from the wild in KZN, while almost half in Limpopo bought insects from towns (46\% from Elim, Sibasa, Louis Trichardt, Makhado-Biaba, and Tshakhuma markets, or Thohoyandou). All the insects consumed are collected from the wild and are not reared for consumption. Gynanisa caterpillars and termites were abundant in the rainy season (from October to January), while stink bugs occurred in the dry season from May to August.

Edible insects are mainly collected in the wild mainly by women and they are prepared using different methods (Table 4). They are eaten either fried, boiled, roasted, sun-dried, or as a relish (Table 4). A greater number of respondents preferred sun-dried $(62 \%)$ edible insects in Limpopo, while fried or roasted edible insects were the most preferred (88\%) cooking method in KwaZulu-Natal.

\section{Discussion}

Entomophagy is an important traditional practice in Africa's different regions $[4,46]$. The current study reported a greater number of respondents consuming insects in their lifetime in Limpopo (98\%) and KwaZulu-Natal (64\%). These results are similar to those of Shackleton et al. [32]. They reported that $96.3 \%$ of the respondents in Ha-Gondo village, $55 \mathrm{~km}$ east of Thohoyandou in Limpopo, used insects as food; by comparison, $67.8 \%$ of the respondents in KwaJobe village in northern KwaZulu-Natal used insects as food. These results indicate that entomophagy is a common practice in South Africa. In addition, Egan [49] reported that $90.5 \%$ of the respondents consume insects in Blouberg Municipality in Limpopo. According to Teffo et al. [15], the consumption of insects in South Africa is more prevalent in Limpopo, Gauteng, North West, and Mpumalanga provinces. Across African countries, Zimbabwe [4-21], Angola [54], Tanzania [36], Nigeria [55], and Botswana [18] have been reported to consume edible insects. However, Ethiopia is one exception, because religious beliefs prohibit the consumption of insects, and only $1 \%$ of people interviewed were prepared to accept insects as a human food [56].

However, the consumption of insects may be declining in some areas, as reported in the current study; only $28 \%$ still consume insects in KwaZulu-Natal. According to Doberman et al. [57], the consumption of insects seems to be declining because of the spread/adoption of western food choices, and the association of insects with fear and discomfort when it comes to eating them. In addition, the way of living is constantly changing, and is being influenced by modern technology and education, resulting in people neglecting traditional practices that formed part of their lifestyle in the past $[50,58]$. Documenting indigenous knowledge about edible insects will preserve long-standing traditional knowledge about edible insects that can help influence planning and decision-making on the sustainable use of insects as a nutritious food that can ensure food security for people in developing countries [50,59].

The choice not to eat insects is primarily influenced by preference, availability of insects, and consumer acceptance [60]. Findings from the current study revealed that religion (for example, the "African-initiated church" such as the Zionist churches) and fear associated with consuming insects were the main reasons influencing the decision not to eat insects. According to van Huis [61], the consumption of insects is perceived as 
unholy, dirty, and unhealthy by some people, particularly in developed countries. For example, Balzan [24] reported that, in Italy, respondents associated insect meals with dirt and food contamination. In addition, Netshifhefhe et al. [31] found that $80.7 \%$ of the respondents in Limpopo cited that some religions are against the consumption of insects, especially traditional churches. Culture plays a significant role in determining acceptance and preference of edible insects. For example, Zonocerous spp (a grasshopper) is consumed as food in Cameroon, Nigeria, and South Africa, but the same species is considered poisonous elsewhere [62]. In addition, cultural beliefs influence how insects should be prepared before consumption [62]. Religious and gender-based taboos also govern the consumption of insects in some regions. For example, religion and customs prohibit women of the Baganda tribe in Uganda from consuming nsenene (Ruspolia differens) [36,62]. There is a need to educate and raise awareness about the consumption of insects through media to promote and encourage people to adopt edible insects as foods, because insects are a sustainable nutritious food which has less impact on the environment [58]. In addition, incorporating insect powder into food products such as bread, biscuits, snack bars, cereal, porridge, and shakes might promote acceptance of insects as food [60].

Sociodemographic factors play a significant role in a person's choice to consume insects [63]. This study found that gender, age, occupation, and educational background were the main factors influencing the choice to eat insects. These results are similar to Anakware et al. [64], a study which found that gender, age, educational background, and occupation significantly influenced people's choice to consume insects in Ghana. Youth, educated, urban dwellers, and middle- and upper-class earners are highly influenced by western culture [65]. As a result, they are adopting western diets and ignoring traditional food such as edible insects. There is a notable shift to adopting Western diets, and a decline in consumption of edible insects, particularly by youth and educated people [65]. This might be the main reason why the consumption of insects is largely practiced in rural areas where high levels of unemployment and people with no formal education are found. In addition, people who are unemployed consume edible insects more because they have to do so to meet nutritional requirement needs.

Eight insect species belonging to five insect orders were used as food in Limpopo and KZN. These results are similar to Obopile and Seeletso's [18] findings, who reported that insects belonging in six insect orders were used as food in Botswana. Contrary to this, Makhado et al. [33] reported that insects belonging in four insect orders were used as food in Greater Giyani Municipality, Limpopo. This suggests that the consumption pattern and preference of insects vary from place to place [66]. According to Raheem et al. [1], insects and preference consumption varies from country to country, and variations can be observed between ethnic groups in different countries. The variation in the number of insects consumed in different countries is attributed to the availability and occurrence of edible insects in the wild [62]. Differences in geographic area and environmental conditions influence the occurrence of different species; for example, mopane worm (Imbrasia belina) occurs in mopane woodlands in Southern Africa and is mostly used as food in this region [67].

Mopane worms and termites were the most preferred and consumed insects in Limpopo and KwaZulu-Natal, respectively. Kelemu et al. [27] reported that mopane worms and termites are the most consumed species in Southern Africa. In addition, they are a popular traditional food in many cultures in Southern Africa [31,68]. According to Baiyegunhi et al. [68], mopane worms are occasional delicacies for different cultures in South Africa. Edible insects are valued natural resources that people collect for food and income in rural areas; they are used as a food security safety net in rural areas where poverty and malnutrition are major problems $[33,67,68]$.

This study found that edible insects are consumed because of their nutritional value and they contribute to nutritional diets in rural areas. Similar results were reported by several previous studies $[4,15,31]$. Netshifhefhe et al. [31] conducted a study looking at the human uses and indigenous knowledge of edible termites in Vhembe district, Limpopo 
province, South Africa, and found that the majority of the respondents consumed edible termites for their nutrition and to enhance their health. Similarly, Manditsera [4] conducted a study on consumption patterns of edible insects in rural and urban areas in Zimbabwe and found that the primary motives for consuming insects in rural and urban areas were nutrition and taste of edible insects. Food shortage and malnutrition are prevalent challenges experienced in rural communities in Southern Africa [38]. Edible insects play an important role in supplementing diets in poor communities across Africa [46]; in addition, edible insects are used to ease food shortages and provide vulnerable communities with nutritious diets that improve human health and wellbeing $[69,70]$.

Climate change is a global problem that reduces precipitation and increases the extended drought in Southern Africa [71,72]. These changes have resulted in the decline of insect availability in the wild [71,73]. Other factors that might affect the availability of edible insects are different land uses such as clearing of land, development, agriculture, and deforestation [61,70,72]. Ndlovu [72] reported that $40 \%$ of the respondents in Zimbabwe cited that the cutting down of mopane trees for fuel use resulted in the decline in mopane worm yields. The decline in the availability of insects affects rural livelihoods and the well-being of the people who depend on insects for food and cash income [61,71]. In addition, this affects the nutrition security of rural populations. Interventions to increase insect yields are required. This can be done by farming and rearing to make insects easily available to people, particularly in vulnerable communities [61,70,71]. In addition, because of their nutritional value, insects can be used as nutritious food alternatives to mainstream animal protein such as pork, chicken, beef, and fish [61,70,71,74].

Insects are mainly harvested in the wild by women. According to Dzerefos et al. [75,76], insects collection and preparation are primarily female-driven tasks, with more than $70 \%$ (in the current study) of females involved in insects harvesting in Limpopo province. Insect preparation and processing methods differ from species to species. The important step is removing unpalatable parts and degutting before washing [77,78]. After washing, insects are then boiled or roasted, then sundried to increase shelf life $[79,80]$. According to Agea et al. [28], sun-drying insects extend the availability of insects and allows traders to have products for a longer period, even when the period of occurrence of insects has passed.

This study reported that edible insects are incorporated in regular diets and they are eaten fried, boiled, roasted, dried, or as a relish. Similar findings were reported by other authors $[4,21,31,81]$. They found that edible insects are eaten fried, boiled, dried, or as a relish. However, in some parts of Africa, edible insects are smoked or eaten raw without preparation $[66,82]$. Tradition and culture influence cooking methods of edible insects. People prepare insects based on the knowledge that has been passed down from older generations; for example, in Limpopo province, South Africa, Encosternum delergorguei (stink bug) is eaten either fried or raw, while in Zimbabwe, the same species is eaten fried or dried but not raw $[15,21]$. In addition, some tribes prohibit the consumption of raw edible insects; in Uganda, the Baganda tribe customs and tradition prohibit the consumption of raw Ruspolia differens [36]. Cooking methods improve the sensory quality of edible insects through the formation of aromatic compounds [83]. According to Gosh et al. [62], sensory characteristics such as taste, texture, odour, colour, and appearance play an important role in food selection, acceptability, and preference. Some cooking methods reduce foodborne and degradative enzymes, which increase the shelf life of edible insects [83].

This study's limitations were that local communities refer to several species from one insect order/genus using the same common vernacular names. Therefore, there might be an underrepresentation of the total number of species consumed in the two provinces. Respondents relied on the pictures from the insect guidebook to identify the correct species they consume; species that were not represented in the book might have been left out of the survey. 


\section{Conclusions}

Edible insects play a crucial role in food and nutrition security in rural communities of Limpopo and KwaZulu-Natal provinces, South Africa. This study recorded eight species belonging to five insect orders that are used as food in these provinces. Indigenous knowledge about the collection and preparation of edible insects needs to be preserved, because it can play an important role in the promotion of edible insects as food. Entomophagy is still practiced in Limpopo and KwaZulu-Natal. However, there is a notable decline in the availability of edible insects and the consumption of insects in KwaZulu-Natal. This is thought to be a result of the adoption of western food culture, religion, fear/discomfort associated with eating insects and the decline in the availability of insects in the wild.

The latter is concerning because people are losing critical traditional practices that play a major role in rural nutrition and livelihoods. Edible insects are highly nutritious and have a lower environmental impact than livestock production [5]. To promote entomophagy, there is an urgent need for education and awareness about edible insects and their benefits to help reduce the stigma, fear, and discomfort associated with eating insects. In addition, documenting indigenous knowledge about the consumption of edible insects in media and literature will help promote edible insects, ensure that indigenous knowledge about edible insects is preserved, and change peoples' perceptions about edible insects. In addition, indigenous knowledge about entomophagy will contribute to local, national, and global knowledge about edible insects, which might help guide the inclusion of edible insects in food policy, enabling the adoption of insects as food that will be included in daily diets and to better understand edible insects as a potential solution to food security problems, particularly in developing countries [49,50]. Future research should focus on the nutritional content of edible insects, and the potential of farming and rearing of edible insects in South Africa to increase the availability of edible insects, and make them easily accessible to people. Government officials should encourage people, especially from vulnerable groups, to include edible insects in their daily diets. To promote acceptability, edible insects could be incorporated into food products. In addition, more research should focus on the acceptability of food products fortified with edible insects.

Author Contributions: Conceptualization, Z.T.H., R.S. and T.C.M. methodology, Z.T.H. and T.C.M.; data collection, Z.T.H. and T.C.M.; data analysis, Z.T.H.; writing—original draft preparation, Z.T.H.; writing - review and editing, R.S., T.C.M. and Z.T.H.; supervision, R.S. and T.C.M.; funding acquisition, R.S. and T.C.M. All authors have read and agreed to the published version of the manuscript.

Funding: This study was funded by the Sustainable and Healthy Food Systems (SHEFs) supported by the Wellcome Trust's Our Planet, our Health programme (grant number, 205200/Z/16/Z), and the DSI-NRF Centre for Indigenous Knowledge Systems (CIKS).

Institutional Review Board Statement: This study has been ethically reviewed and approved by the University of KwaZulu-Natal Human and Social Sciences Research Ethics Committee (approval number HSS/0125/019D). Permission to conduct research in various villages in all the local municipalities was obtained from community leaders.

Informed Consent Statement: All participants provided informed consent to participate in the study, and data were anonymised, treated confidentially, and stored securely.

Data Availability Statement: The data presented in this study are available in the tables, figures as well as appendices of the current manuscript.

Acknowledgments: This study forms part of the Sustainable and Healthy Food Systems (SHEFs) supported by the Wellcome Trust's Our Planet, our Health programme (grant number, 205200/Z/16/Z). We would like to thank Alfred Munyai, Vhutshilo Muthavhini, Nobuhle Mweli and Naledi Zama for assisting with conducting questionnaires. Lastly, we would like to thank the Centre for Functional Biodiversity for funding field work expenses.

Conflicts of Interest: The authors declare no conflict of interest. The funders had no role in the design of the study; in the collection, analyses, or interpretation of data; in the writing of the manuscript, or in the decision to publish the results. 


\section{Appendix A}

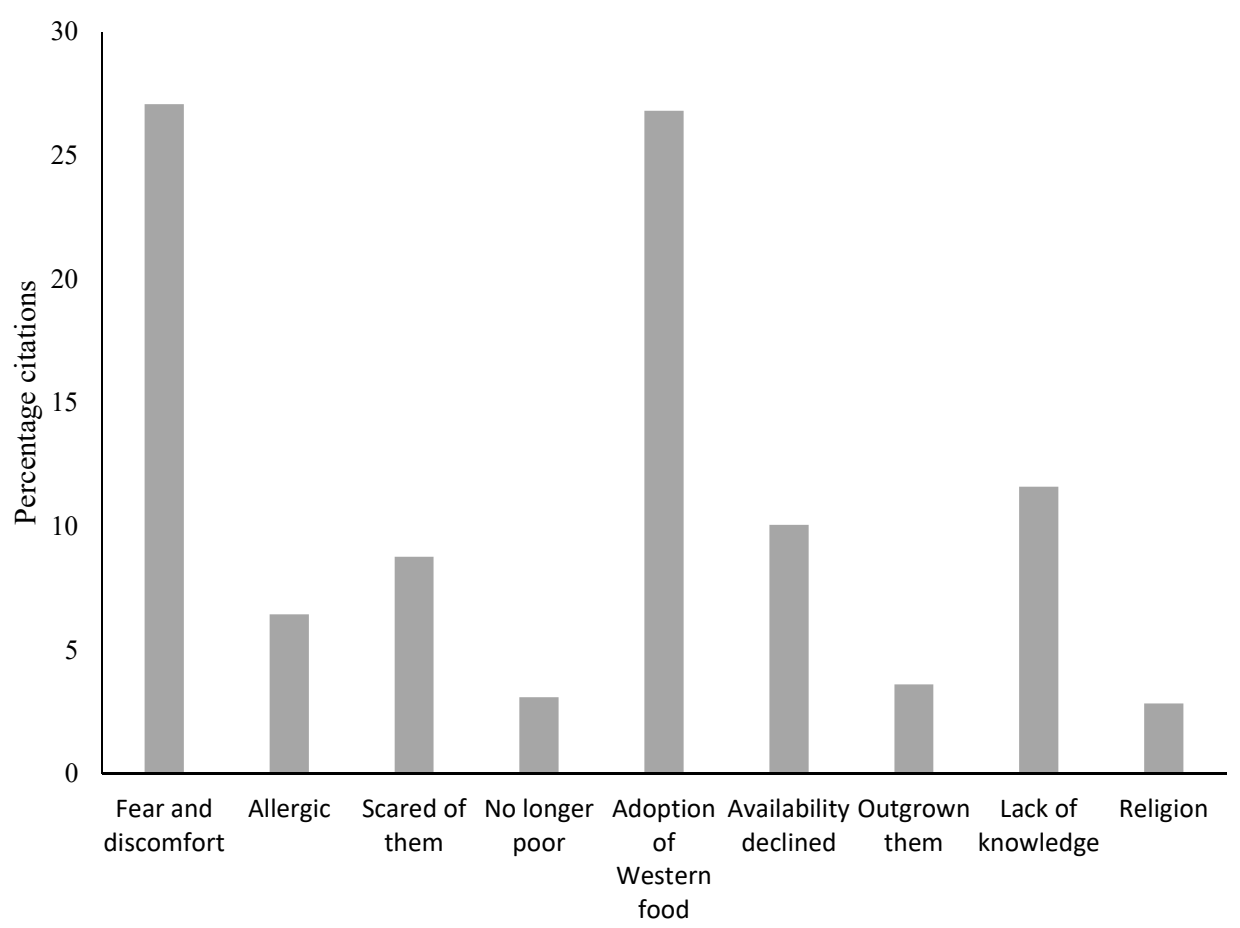

Reasons for not consuming insects

Figure A1. Cited reasons for not consuming insects in KwaZulu-Natal province $(n=356)$.

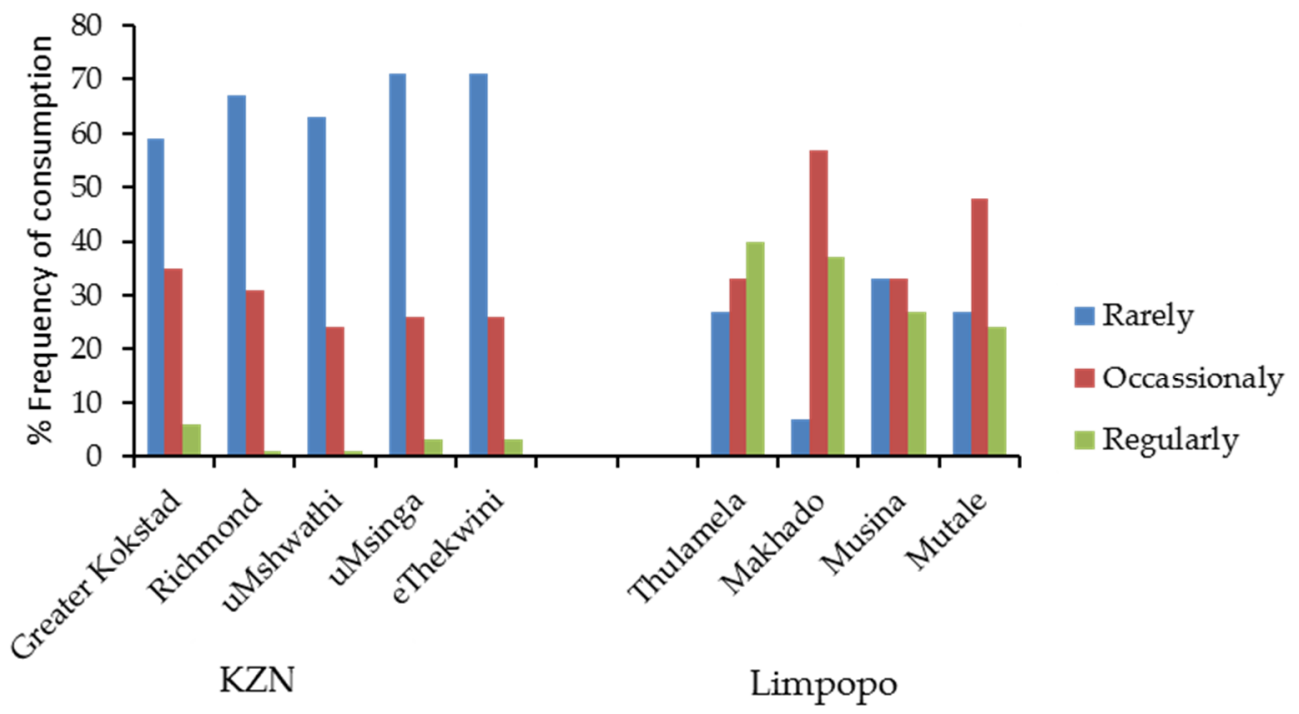

Figure A2. Frequency of insect consumption per week and month across municipalities in KwaZulu-Natal and Vhembe district, Limpopo. Rarely consume insects (at least once a month), occasionally (1-4 times a month), regularly (1-4 times a week). 
Table A1. Number of villages sampled in different local municipalities in Limpopo and KwaZuluNatal.

\begin{tabular}{|c|c|c|}
\hline Village & Local Municipality & GPS Coordinates \\
\hline & Limpopo province & \\
\hline Muwaweni & Makhado & $23.3283^{\circ} \mathrm{S}, 30.1113^{\circ} \mathrm{E}$ \\
\hline Elim & Makhado & $23.1561^{\circ} \mathrm{S}, 30.0554^{\circ} \mathrm{E}$ \\
\hline Biaba & Makhado & $22.5344^{\circ} \mathrm{S}, 30.1126^{\circ} \mathrm{E}$ \\
\hline Tshikuwi & Makhado & $22.9013^{\circ} \mathrm{S}, 29.9480^{\circ} \mathrm{E}$ \\
\hline Tshiozwi & Makhado & $23.0855^{\circ} \mathrm{S}, 29.7860^{\circ} \mathrm{E}$ \\
\hline Ha Mashau Doli & Makhado & $23.1583^{\circ} \mathrm{S}, 30.1897^{\circ} \mathrm{E}$ \\
\hline Ha mashau Mathothe & Makhado & $23.1462^{\circ} \mathrm{S}, 30.1979^{\circ} \mathrm{E}$ \\
\hline Masia & Makhado & $23.2170^{\circ} \mathrm{S}, 30.3299^{\circ} \mathrm{E}$ \\
\hline Tshikota & Makhado & $23.0492^{\circ} \mathrm{S}, 29.8772^{\circ} \mathrm{E}$ \\
\hline Mashamba & Makhado & $23.0538^{\circ} \mathrm{S}, 30.3527^{\circ} \mathrm{E}$ \\
\hline Mulima-Lambani & Makhado & $22.430^{\circ} \mathrm{S}, 30.500^{\circ} \mathrm{E}$ \\
\hline Nancefield & Musina & $22.3813^{\circ} \mathrm{S}, 30.0319^{\circ} \mathrm{E}$ \\
\hline Mbodi tshafhasi & Mutale & $22.5433^{\circ} \mathrm{S}, 30.7451^{\circ} \mathrm{E}$ \\
\hline Shakadza & Mutale & $22.6160^{\circ} \mathrm{S}, 30.5711^{\circ} \mathrm{E}$ \\
\hline Tshipise & Mutale & $22.5349^{\circ} \mathrm{S}, 30.6703^{\circ} \mathrm{E}$ \\
\hline Mukondeni & Makhado & $23.2559^{\circ} \mathrm{S}, 30.1041^{\circ} \mathrm{E}$ \\
\hline Tshivhulani & Thulamela & $23.1316^{\circ} \mathrm{S}, 30.4386^{\circ} \mathrm{E}$ \\
\hline Vhurivhuri & Thulamela & $22.7008^{\circ} \mathrm{S}, 30.8056^{\circ} \mathrm{E}$ \\
\hline Halambani & Thulamela & $22.7108^{\circ} \mathrm{S}, 30.8442^{\circ} \mathrm{E}$ \\
\hline Ha-Lambani & Thulamela & $22.7108^{\circ} \mathrm{S} 30.8442^{\circ} \mathrm{E}$ \\
\hline Mushiru & Thulamela & $22.7662^{\circ} \mathrm{S}, 30.8431^{\circ} \mathrm{E}$ \\
\hline \multirow[t]{2}{*}{ MukulaVyeboom } & ThulamelaMakhado & $\begin{array}{l}22.8628^{\circ} \mathrm{S}, 30.5754^{\circ} \mathrm{E} \\
23.1488^{\circ} \mathrm{S}, 30.3861^{\circ} \mathrm{E}\end{array}$ \\
\hline & \multicolumn{2}{|c|}{ KwaZulu-Natal province } \\
\hline Umbumbulu & eThekwini & $29.5902^{\circ} \mathrm{S}, 30.4207^{\circ} \mathrm{E}$ \\
\hline Nhlazuka & Richmond & $29.3759^{\circ} \mathrm{S}, 30.100^{\circ} \mathrm{E}$ \\
\hline Swayimane & uMshwathi & $29.4878^{\circ} \mathrm{S}, 30.6603^{\circ} \mathrm{E}$ \\
\hline Tugela Ferry & Umsinga & $28.7416^{\circ} \mathrm{S}, 30.4617^{\circ} \mathrm{E}$ \\
\hline Kokstad & Greater Kokstad & $30.5096^{\circ} \mathrm{S}, 29.4063^{\circ} \mathrm{E}$ \\
\hline
\end{tabular}

Appendix B. Questionnaire Used to Source Information in Limpopo and KwaZulu-Natal

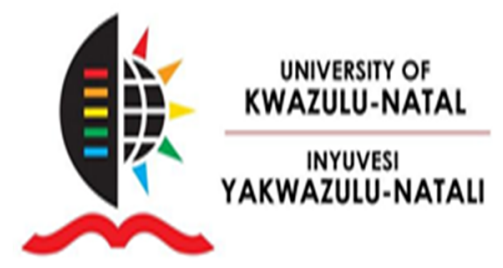

Project Tittle: Diversity of Edible Insects and Their Related Indigenous Knowledge by Human in Limpopo and KwaZulu-Natal Province, South Africa

You are being invited to consider participating in a study that involves research on the consumption of edible insects using indigenous knowledge in South Africa, we would like to get insight on the socio-economic benefits, drivers of consuming edible insects and the attitude people have towards edible insects. The aim of this research is to determine diversity and distribution of edible insects using indigenous knowledge in South Africa. Please note that your participation in this research is voluntary and you may choose not to participate or you may discontinue your participation at any time without penalty or disadvantage to yourself.

In case there are questions considering the survey, please contact Zabentungwa Hlongwane (0737076460 or email nolwazihlongwane20@gmail.com)

Awareness and perception 
Date:

Questionnaire number:

Location:

Has the informed consent being signed by the participant Yes [ ]/No [ ]

\section{Questionnaires}

1. Gender Male [ ] Female [ ]

2. Age category

$$
\begin{aligned}
& \text { - Under } 18 \text { years [ ] } \\
& \text { - 18-24 years [ ] } \\
& \text { - 25-34 years [ ] } \\
& \text { - 35-44 years [ ] } \\
& \text { - 45-54 years [ ] } \\
& \text { - 55-64 years [ ] } \\
& \text { - 65-74 years [] } \\
& \text { - } 75 \text { or older [] }
\end{aligned}
$$

3. Level of education
- Level 0 []
- Primary school []
- High school []
- Undergraduate [ ]
- Post graduate []

4. Employment status: unemployed [ ] self-employed [ ] pensioner [ ] employed [ ]

5. Have you ever eaten insects? Yes [ ] or No [ ] if No go to question number 15

6. If yes how often do you consume insects

$$
\begin{array}{ll}
\text { - } & \text { Rarely [ ] } \\
\text { - } & \text { Occasionally [ ] } \\
\text { - } & \text { Regularly [] }
\end{array}
$$

7. How do you prepare and eat edible insects
- Dried []
- Fried [ ]
- Stew (socked in clean water for $30 \mathrm{~min}$, drain water, fried with onions, toma- toes, chili, curry powder and salt) [ ]
- Please share your recipe of how you cook edible insects for consumption

- How did your mother cook edible insects when you were growing up

8. Where do you buy or harvest edible insect
- Local markets []
- City markets (Thohoyandou, Sibasa, Elim, Makhado or
- Harvest from the wild [ ]

9. Why do you consume insects
- Nutritious benefits []
- Cultural beliefs [ ]
- Cheap and abundantly available [ ]
- Buffer during times of food shortage [ ]
- All of the above [ ]

10. How long have you been consuming insects 
11. How many orders of insects are edible in your area

12. What season are edible insects mostly available

$\begin{array}{ll}\text { - } & \text { Spring [ ] } \\ \text { - } & \text { Summer [ ] } \\ \text { - } & \text { Autumn [ ] } \\ \text { - } & \text { Winter [ ] } \\ \text { - } & \text { Available all year [ ] }\end{array}$

13. There are many benefits of consuming insects, which of the following interest you the most?

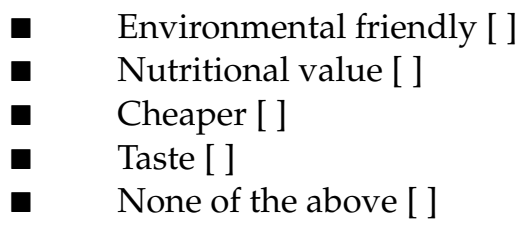

14. Would you ever consider eating insects? Yes [ ] or No [ ]

15. Do you know anything about edible insects. Yes [ ] or No [ ]

16. What can be done to promote eating of insects.

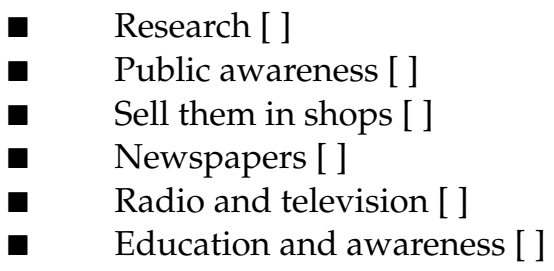

17. Are you aware of the nutritional benefits of eating insects yes [ ] or no [ ]

18. Would you be more comfortable eating insects if there were hidden in food? (covered in chocolate, cookies) yes [ ] or no [ ]

19. Which insect do you consume or would you consider eating

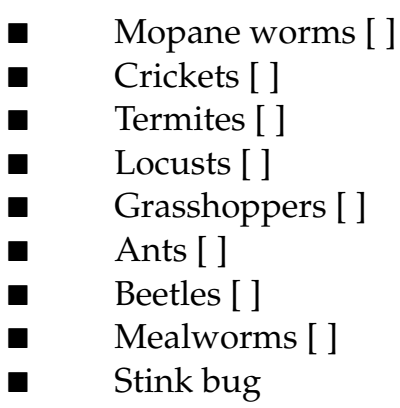

20. Why did you stop eating insects?

21. Is there anything you would like to tell us regarding the eating of insects by human?

\section{References}

1. Raheem, D.; Carrascosa, C.; Oluwole, O.B.; Nieuwland, M.; Saraiva, A.; Millán, R.; Raposo, A. Traditional consumption of and rearing edible insects in Africa, Asia and Europe. Crit. Rev. Food Sci. Nutr. 2019, 59, 2169-2188. [CrossRef] [PubMed]

2. Fasoranti, J.O.; Ajiboye, D. Some edible insects of Kwara State, Nigeria. Am. Entomol. 1993, 39, 113-116. [CrossRef]

3. Muafor, F.J.; Levang, P.; Le Gall, P. A crispy delicacy: Augosoma beetle as alternative source of protein in East Cameroon. Int. J. Biodivers. 2014, 2014, 1-7. [CrossRef]

4. Manditsera, F.A.; Lakemond, C.M.M.; Fogliano, V.; Zvidzai, C.J.; Luning, P.A. Consumption patterns of edible insects in rural and urban areas of Zimbabwe: Taste, nutritional value and availability are key elements for keeping the insect eating habit. Food Secur. 2018, 10, 561-570. [CrossRef] 
5. Hlongwane, Z.T.; Slotow, R.; Munyai, T.C. Nutritional composition of edible insects consumed in africa: A systematic review. Nutrients 2020, 12, 2786. [CrossRef]

6. Costa-Neto, E.M. Anthropo-entomophagy in Latin America: An overview of the importance of edible insects to local communities. J. Insects Food Feed 2015, 1, 17-23. [CrossRef]

7. Feng, Y.; Chen, X.M.; Zhao, M.; He, Z.; Sun, L.; Wang, C.Y.; Ding, W.F. Edible insects in China: Utilization and prospects. Insect Sci. 2018, 25, 184-198. [CrossRef]

8. Chen, X.; Feng, Y.; Chen, Z. Common edible insects and their utilization in China: Invited review. Entomol. Res. 2009, 39, 299-303. [CrossRef]

9. Hanboonsong, Y.; Jamjanya, T.; Durst, P.B. Six-Legged Livestock: Edible Insect Farming, Collect on and Market in Thailand; Food and Agriculture Organization of the United Nations Regional Office for Asia and The Pacific: Bangkok, Thailand, $2013 ;$ pp. 1-57.

10. Ramos-Elorduy, J.; Moreno, J.M.P. Edible insects of Chiapas, Mexico. Ecol. Food Nutr. 2002, 41, 271-299. [CrossRef]

11. Hurd, K.J.; Shertukde, S.; Toia, T.; Trujillo, A.; Pérez, R.L.; Larom, D.L.; Love, J.J.; Liu, C. The cultural importance of edible insects in Oaxaca, Mexico. Ann. Entomol. Soc. Am. 2019, 112, 552-559. [CrossRef]

12. Payne, C.L.R. Wild harvesting declines as pesticides and imports rise: The collection and consumption of insects in contemporary rural Japan. J. Insects Food Feed 2015, 1, 57-65. [CrossRef]

13. Nonaka, K. Feasting on insects. Entomol. Res. 2009, 39, 304-312. [CrossRef]

14. Alamu, T.O.; Amao, O.A.; Nwokedi, I.C.; Oke, A.O.; Lawa, O. Diversity and nutritional status of edible insects in Nigeria: A review. Int. J. Biodivers. Conserv. 2013, 5, 215-222. [CrossRef]

15. Teffo, L.S.; Toms, R.B.; Eloff, J.N. Preliminary data on the nutritional composition of the edible stink-bug, Encosternum delegorguei Spinola, consumed in Limpopo province, South Africa. S. Afr. J. Sci. 2007, 103, 434-436.

16. Anankware, J.P.; Osekre, E.A.; Obeng-Ofori, D.; Khamala, C. Identification and classification of common edible insects in Ghana. Int. J. Entomol. Res. 2016, 1, 2455-4758.

17. Musundire, R.; Zvidzai, C.J.; Chidewe, C.; Samende, B.K.; Chemura, A. Habitats and nutritional composition of selected edible insects in Zimbabwe. J. Insects Food Feed 2016, 2, 189-198. [CrossRef]

18. Obopile, M.; Seeletso, T.G. Eat or not eat: An analysis of the status of entomophagy in Botswana. Food Secur. 2013, 5, 817-824. [CrossRef]

19. Ghaly, A.E. The use of insects as human food in Zambia. Online J. Biol. Sci. 2009, 9, 93-104. [CrossRef]

20. Quin, P. Foods and Feeding Habits of the Pedi. Ph.D. Thesis, University of the Witwaterstand, Johannesburg, South Africa, 1959.

21. Dube, S.; Dlamini, N.R.; Mafunga, A.; Mukai, M.; Dhlamini, Z. A survey on entomophagy prevalence in Zimbabwe. Afr. J. Food Agric. Nutr. Dev. 2013, 13, 7242-7253. [CrossRef]

22. Niassy, S.; Affognon, H.D.; Fiaboe, K.K.M.; Akutse, K.S.; Tanga, C.M.; Ekesi, S. Some key elements on entomophagy in Africa: Culture, gender and belief. J. Insects Food Feed 2016, 2, 139-144. [CrossRef]

23. Yen, A.L. Edible insects: Traditional knowledge or western phobia? Entomol. Res. 2009, 39, 289-298. [CrossRef]

24. Balzan, S.; Fasolato, L.; Maniero, S.; Novelli, E. Edible insects and young adults in a north-east Italian city an exploratory study. Br. Food J. 2016, 118, 318-326. [CrossRef]

25. Sogari, G.; Menozzi, D.; Hartmann, C.; Mora, C. How to measure consumers acceptance towards edible insects?-A scoping review about methodological approaches. In Edible Insects in the Food Sector; Springer: Cham, Switzerland, 2019; pp. 27-44.

26. Mancini, S.; Sogari, G.; Menozzi, D.; Nuvoloni, R.; Torracca, B.; Moruzzo, R.; Paci, G. Factors predicting the intention of eating an insect-based product. Foods 2019, 8, 270. [CrossRef] [PubMed]

27. Kelemu, S.; Niassy, S.; Torto, B.; Fiaboe, K.; Affognon, H.; Tonnang, H.; Maniania, N.K.; Ekesi, S. African edible insects for food and feed: Inventory, diversity, commonalities and contribution to food security. J. Insects Food Feed 2015, 1, 103-119. [CrossRef]

28. Agea, J.; Biryomumaisho, D.; Buyinza, M.; Nabanoga, G. Commercialization of Ruspolia nitidula (nsenene grasshoppers) in Central Uganda. Afr. J. Food Agric. Nutr. Dev. 2008, 8, 319-332. [CrossRef]

29. Ledger, J.A. Arthropoda at Melville Koppies Useful as Food Forman or Producing Food Materials in Prehistoric Man in Johannesburg. The Archeology and Human Ecology of Melville Koppies Nature Reserve, Johannesburg. Possible Relation between Man, Plants, Animals, Insects and Environment at Melville Koppies from Prehistoric times up to the 19th century. The Johannesburg Council for Natural History; Occasional Paper; Department of Archeology, University of Witwaterstrand, Johannesburg: Johannesburg, South Africa, 1971; Volume 6.

30. Bodenheimer, F.S. Insects as Human Food; Springer: Dordrecht, The Netherlands, 1951; pp. 395-399. [CrossRef]

31. Netshifhefhe, S.R.; Kunjeku, E.C.; Duncan, F.D. Human uses and indigenous knowledge of edible termites in Vhembe District, Limpopo Province, South Africa. S. Afr. J. Sci. 2018, 114, 1-10. [CrossRef]

32. Shackleton, S.E.; Shackleton, C.M.; Netshiluvhi, T.R.; Geach, B.S.; Ballance, A.; Fairbanks, D.H.K. Use patterns and value of savanna resources in three rural villages in South Africa. Econ. Bot. 2002, 56, 130-146. [CrossRef]

33. Makhado, R.A.; Von Maltitz, G.P.; Potgieter, M.J.; Wessels, D.C.J. Contribution of woodland products to rural livelihoods in the northeast of Limpopo province, South Africa. S. Afr. Geogr. J. 2009, 91, 46-53. [CrossRef]

34. Makhado, R.; Potgieter, M.; Timberlake, J.; Gumbo, D. A review of the significance of mopane products to rural people's livelihoods in southern Africa. Trans. R. Soc. S. Afr. 2014, 69, 117-122. [CrossRef] 
35. Sekonya, J.G.; Mcclure, N.J.; Wynberg, R.P. New pressures, old foodways: Governance and access to edible mopane caterpillars, Imbrasia (=Gonimbrasia) belina, in the context of commercialization and environmental change in South Africa. Int. J. Commons 2020, 14, 139-153. [CrossRef]

36. Mmari, M.W.; Kinyuru, J.N.; Laswai, H.S.; Okoth, J.K. Traditions, beliefs and indigenous technologies in connection with the edible longhorn grasshopper Ruspolia differens (Serville 1838) in Tanzania. J. Ethnobiol. Ethnomed. 2017, 13, 1-12. [CrossRef] [PubMed]

37. Van Huis, A. Edible insects contributing to food security? Agric. Food Secur. 2015, 4, 1-9. [CrossRef]

38. Bain, L.E.; Awah, P.K.; Geraldine, N.; Kindong, N.P.; Siga, Y.; Bernard, N.; Tanjeko, A.T. Malnutrition in Sub—Saharan Africa: Burden, causes and prospects. Pan Afr. Med. J. 2013, 15, 1-9. [CrossRef] [PubMed]

39. Vorster, H.H. The link between poverty and malnutrition: A South African perspective. Health SA Gesondheid 2010, 15, 1-6. [CrossRef]

40. Belluco, S.; Losasso, C.; Maggioletti, M.; Alonzi, C.C.; Paoletti, M.G.; Ricci, A. Edible insects in a food safety and nutritional perspective: A critical review. Compr. Rev. Food Sci. Food Saf. 2013, 12, 296-313. [CrossRef]

41. Parker, M.E.; Zobrist, S.; Lutterodt, H.E.; Asiedu, C.R.; Donahue, C.; Edick, C.; Mansen, K.; Pelto, G.; Milani, P.; Soor, S.; et al. Evaluating the nutritional content of an insect-fortified food for the child complementary diet in Ghana. BMC Nutr. 2020, 6, 1-11. [CrossRef]

42. Tao, J.; Li, Y.O. Edible insects as a means to address global malnutrition and food insecurity issues. Food Qual. Saf. 2018, 2, 17-26. [CrossRef]

43. Gahukar, R.T. Edible insects collected from forests for family livelihood and wellness of rural communities: A review. Glob. Food Secur. 2020, 25, 25. [CrossRef]

44. Meyer-Rochow, V.B. Can Insects hekp to ease the problem of worlf food shortage. Search 1975, 6, 261-262. [CrossRef]

45. Agbidye, F.; Ofuya, T.; Akindela, S. Some edible insect species consumed by the people of Benue State, Nigeria. Pak. J. Nutr. 2009, 8, 946-950. [CrossRef]

46. Niassy, S.; Fiaboe, K.K.M.; Affognon, H.D.; Akutse, K.S.; Tanga, M.C.; Ekesi, S. African indigenous knowledge on edible insects to guide research and policy. J. Insects Food Feed 2016, 2, 161-170. [CrossRef]

47. Mbabazi, M.; Byaruhanga, Y.; Alwala, T. Edible insects in Eastern and Southern Africa: Challenges and opportunities. In Sustainable Diets and Biodiversity: Directions and Solutions for Policy, Research and Action, Proceedings of the International Symposium on Biodiversity and Sustainable Diets United Against Hunger, 3-5 November 2010; Burlingame, B., Dernini, S., Eds.; FAO Headquarters: Rome, Italy, 2012.

48. Rahman, A.; Bordoloi, S.; Mazid, S. Entomophagy practiced among the Tiwa community of Morigaon district. Assam 2018, $6,484-486$.

49. Egan, B.A. Culturally and Economically Significant Insects in the Blouberg Region, Limpopo Province, South Africa. Ph.D. Thesis, University of Limpopo, Polokwane, South Africa, 2013.

50. Ngulube, P. Managing and preserving indigenous knowledge in the knowledge management era: Challenges and opportunities for information professionals. Inf. Dev. 2002, 18, 95-102. [CrossRef]

51. Department of Cooperative Governance and Traditional Affairs. Profile and Analysis District Development Model: Vhembe District Municipality. Available online: https://www.cogta.gov.za/ddm/wp-content/uploads/2020/07/District_Profile_VHEMBE. pdf (accessed on 8 December 2020).

52. StatsSA. Mid Year Population Estimates. 2019. Available online: http://www.statssa.gov.za/?page_id=964 (accessed on 8 December 2020).

53. Picker, M.; Griffiths, C.; Weaving, A. Field Guide to the Insects of South Africa, 3rd ed.; Struik Nature Publishers: Cape Town, South Africa, 2008; pp. 1-527.

54. Lautenschläger, T.; Neinhuis, C.; Monizi, M.; Mandombe, J.L.; Förster, A.; Henle, T.; Nuss, M. Edible insects of Northern Angola. Afr. Invertebr. 2017, 58, 55-82. [CrossRef]

55. Banjo, A.D.; Lawal, O.A.; Songonuga, E.A. The nutritional value of fourteen species of edible insects in southwestern Nigeria. Afr. J. Biotechnol. 2006, 5, 298-301. [CrossRef]

56. Ghosh, S.; Jung, C.; Meyer-Rochow, V.B.; Dekebo, A. Perception of entomophagy by residents of Korea and Ethopia revealed through structure questionnaire. J. Insects Food Feed 2020, 6, 59-64. [CrossRef]

57. Dobermann, D.; Swift, J.A.; Field, L.M. Opportunities and hurdles of edible insects for food and feed. Nutr. Bull. 2017, 42, 293-308. [CrossRef]

58. Barennes, H.; Phimmasane, M.; Rajaonarivo, C. Insect consumption to address undernutrition, a national survey on the prevalence of insect consumption among adults and vendors in Laos. PLoS ONE 2015, 10, e0136458. [CrossRef]

59. Adebayo, C.; Oluwaseye, J.; Adeyemo, A.A. Documenting and disseminating Agricultural Indigenous Knowledge for Sustainable food security: The efforts of agricultural research libraries in Nigeria. In Information Systems for Indigenous Knowledge in AgricultureAgricultural Libraries Special Interest Group, World Library and Information Congress: 77th IFLA General Conference and Assembly, San Juan, PR, 13-18 August 2011; FAO Headquarters: Rome, Italy, 2011.

60. Awobusuyi, T.D.; Pillay, K.; Siwela, M. Consumer acceptance of biscuits supplemented with a sorghum-Insect meal. Nutrients 2020, 12, 895. [CrossRef]

61. van Huis, A. Potential of insects as food and feed in assuring food security. Annu. Rev. Entomol. 2013, 58, 563-583. [CrossRef] 
62. Ghosh, S.; Jung, C.; Meyer-Rochow, V.B. What governs selection and acceptance of edible insects. Edible Insects Sustain. Food Syst. 2019, 1-479. [CrossRef]

63. Cicatiello, C.; De Rosa, B.; Franco, S.; Lacetera, N. Consumer approach to insects as food: Barriers and potential for consumption in Italy. Br. Food J. 2016, 118, 2271-2286. [CrossRef]

64. Anankware, P.J.; Osekre, E.A.; Obeng-Ofori, D.; Khamala, C.M. Factors that affect entomophagical practices in Ghana. J. Insects Food Feed 2017, 3, 33-41. [CrossRef]

65. Imathiu, S. Benefits and food safety concerns associated with consumption of edible insects. NFS J. 2020, 18, 1-11. [CrossRef]

66. Séré, A.; Bougma, A.; Ouilly, J.T.; Traoré, M.; Sangaré, H.; Lykke, A.M.; Ouédraogo, A.; Gnankiné, O.; Bassolé, I.H.N. Traditional knowledge regarding edible insects in Burkina Faso. J. Ethnobiol. Ethnomed. 2018, 14, 1-12. [CrossRef] [PubMed]

67. Baiyegunhi, L.J.S.; Oppong, B.B.; Senyolo, M.G. Socio-economic factors influencing mopane worm (Imbrasia belina) harvesting in Limpopo Province, South Africa. J. For. Res. 2016, 27, 443-452. [CrossRef]

68. Baiyegunhi, L.J.S.; Oppong, B.B.; Senyolo, G.M. Mopane worm (Imbrasia belina) and rural household food security in Limpopo province, South Africa. Food Secur. 2016, 8, 153-165. [CrossRef]

69. Meyer-Rrochow, V.B.; Nonaka, K.; Boulidam, S. More feared than revered: Insects and their impact on human societies with some specific data on the importance of entomophagy in a Laotian Setting). Entomol. Heute 2008, 20, 3-25.

70. Food and Argriculture Organization of the United Nations. Edible Insects: Future Prospects for Food and Feed Security; FAO Forestry Paper; FAO: Rome, Italy, 2013.

71. Mataboge, M.S.; Mulaudzi, F.M.; Wenhold, F.A.M.; Nkunika, P.O.Y.; Dlamini, N.R.; Alders, R.G. Effects of climate variability on the harvesting and preservation of Mopani worms. Indilinga Afr. J. Indig. Knowl. Syst. 2016, 15, 34-38.

72. Ndlovu, I.; Nunu, W.N.; Mudonhi, N.; Dube, O.; Maviza, A. Land use-land cover changes and Mopani worm harvest in Mangwe District in Plumtree, Zimbabwe. Environ. Syst. Res. 2019, 8, 11. [CrossRef]

73. Ayieko, M.A.; Ndonga, M.F.O.; Tamale, A. Climate change and the abundance of edible insects in the Lake Victoria Region. J. Cell Anim. Biol. 2010, 4, 112-118.

74. Akhtar, Y.; Isman, M.B. Insects as an alternative protein Source. Food Sci. Nutr. 2018, 2, 263-288. [CrossRef]

75. Dzerefos, C.M.; Tadeusz, E.; Witkowski, F.; Toms, R. Comparative ethnoentomology of edible stinkbugs in southern Africa and sustainable management considerations. J. Ethnobiol. Ethnomed. 2013, 9, 20. [CrossRef] [PubMed]

76. Dzerefos, C.M.; Witkowski, E.T.; Toms, R. Use of the stinkbug, Encosternum delegorguei (Hemiptera, Tessaratomidae), for food and income in South Africa. Soc. Natr. Resour. 2014, 27, 882-897. [CrossRef]

77. Narzari, S.; Sarmah, J. A study of the prevalence of entomophagy among the Bodos of Assam. J. Entomol. Zool. Stud. 2015, 3, 315-320.

78. Mutungi, C.; Irungu, F.G.; Nduko, J.; Mutua, F.; Affognon, H.; Nakimbugwe, D.; Ekesi, S.; Fiaboe, K.K.M. Postharvest processes of edible insects in Africa: A review of processing methods, and the implications for nutrition, safety and new products development. Crit. Rev. Food Sci. Nutr. 2019, 59, 276-298. [CrossRef]

79. Nyangena, D.N.; Mutungi, C.; Imathiu, S.; Kinyuru, J.; Affognon, H.; Ekesi, S.; Nakimbugwe, D.; Fiaboe, K.K.M. Effects of traditional processing techniques on the nutritional and microbiological quality of four edible insect species used for food and feed in East Africa. Foods 2020, 9, 574. [CrossRef]

80. Akullo, J.; Agea, J.G.; Obaa, B.B.; Okwee-Acai, J.; Nakimbugwe, D. Nutrient composition of commonly consumed edible insects in the Lango sub-region of northern Uganda. Int. Food Res. J. 2018, 25, 159-166.

81. Manditsera, F.A.; Luning, P.A.; Fogliano, V.; Lakemond, C.M.M. Effect of domestic cooking methods on protein digestibility and mineral bioaccessibility of wild harvested adult edible insects. Food Res. Int. 2019, 121, 404-411. [CrossRef]

82. Kouřimská, L.; Adámková, A. Nutritional and sensory quality of edible insects. NFS J. 2016, 4, 22-26. [CrossRef]

83. Melgar-Lalanne, G.; Hernández-Álvarez, A.J.; Salinas-Castro, A. Edible Insects Processing: Traditional and Innovative Technologies. Compr. Rev. Food Sci. Food Saf. 2019, 18, 1166-1191. [CrossRef] [PubMed] 